\title{
Application and efficacy of levetiracetam in prophylactic treatment of migraine without aura
}

\author{
TN Maykova \\ From The European Headache and Migraine Trust International Congress \\ London, UK. 20-23 September 2012
}

\section{Introduction}

In connection with necessity of extension of therapeutic possibilities of migraine treatment the study of efficacy of Levetiracetam for profilactic treatment was conducted. There are not data in literature on undertaking big randomized studies on this topic.

\section{Background}

With a glance for pharmacotherapeutic peculiarities of action of traditional anticonvulsants, that limit their application due to side-effects (valproic acid and topiramate are meant), there is a necessity of enlargement of the range of drugs, that can be used for the prophylactic treatment of migraine.

\section{Objectives and methods}

The study was conducted on the base of Headache Center on patients that applied with migraine without aura [1] with attacks resistant to NSAID or triptans, or frequent attacks (4-8 per month). Patients were randomized on gender, age, duration of the disease. 30 patients took Levetiracetam $(1000 \mathrm{mg} /$ day) like prophylactic treatment for 6 months, 30 patients took valproic acid ( $1000 \mathrm{mg} /$ day) for 6 months, and 30 patients took Topiramate $(200 \mathrm{mg} /$ day) for 6 months. Efficacy of the treatment was assessed by quantity of days with headache during the month, quality of life index [2].

\section{Results}

Levetiracetam showed efficacy comparable with traditionally used anticonvulsants. The efficacy of Levetiracetam was unreliably lower than the efficacy of valproic acid, and it was reliably higher than the efficacy of Topiramate.

\section{References}

1. International Headache Society Classification Subcommittee: International classification oh headache disorders. Cephalalgia, 22004.

2. Mezzich JE, Cohen N, Liu J, et al: Validation of an efficient quality of life index: Abstract of the XI World Congress of Psychiatry. Psychiatry on New Thresholds Hamburg, Germany; 1999, 427-428.

doi:10.1186/1129-2377-14-S1-P207

Cite this article as: Maykova: Application and efficacy of levetiracetam in prophylactic treatment of migraine without aura. The Journal of Headache and Pain 2013 14(Suppl 1):P207.
Submit your manuscript to a SpringerOpen ${ }^{\odot}$ journal and benefit from:

- Convenient online submission

- Rigorous peer review

- Immediate publication on acceptance

- Open access: articles freely available online

- High visibility within the field

Retaining the copyright to your article 